that is the one which I have already emphasized-the education of the public. To one who has had occasion to interview our legislators, both national and state, in behalf of public health affairs, the situation often becomes most depressing. The task seems hopeless and one is inclined to forego all effort. Men high in the councils of the nation say without hesitation that this talk about stamping out tuberculosis is only a doctor's fad. As one listens to such talk, as I have, from high sources, his national pride hides its face in shame and he wonders to what destination his country is drifting with such colossal igmorance guiding its course. But, as medical educators our duty is clear, and it has fallen to us to prepare the next generation of those who will be able to render a far greater service to human progress than the world has yet seen. With the race freed from disease, both inherited and acquired, the better man will be born and will dominate the earth. I am not enough of a prophet to predict anything concerning the nationality of the superman who is to come and possess the earth, but he will not come to a diseaseridden people, for the intellectuality and morality of a nation depend upon its physical health, and the historian of the future will have no difficulty in convincing his readers that we who lived in the early part of the twentieth century were not so wise as we believed ourselves to be, as he points out our high mortality rate from preventable diseases, and shows what feeble efforts were made to prevent them.

VICTOR C. VAUGHAN

\section{THE NUMBER OF STUDENTS IN GERMAN UNIVERSITIES}

Some statistics regarding the number of students in the twenty-one German universities, which have lately appeared in the Frankfurter Zeitung, may be of interest to the readers of ScIENCE.
The number of students matriculated in the summer semester of 1909 reached the total of 51,510, as compared with 48,717 in the winter of 1908-09, and 47,799 in the preceding summer.

In thirty years the increase has been as follows:

$\begin{array}{ccc}\text { Year } & \text { No. of Students } & \begin{array}{c}\text { Per } 100,000 \\ \text { Population }\end{array} \\ 1879 & 19,771 & 43.7 \\ 1889 & 29,491 & - \\ 1899 & 33,563 & - \\ 1909 & 51,510 & 78.4\end{array}$

The relative increase in the principal subdivisions may be shown in the following table:

\begin{tabular}{|c|c|c|c|c|}
\hline \multirow{3}{*}{$\begin{array}{l}\text { Philological and his- } \\
\text { torical studies .. }\end{array}$} & \multicolumn{2}{|c|}{ Number } & \multicolumn{2}{|c|}{$\begin{array}{l}\text { Per } 100,000 \\
\text { Population }\end{array}$} \\
\hline & 1879 & 1909 & 1879 & 1809 \\
\hline & 2,724 & 7,690 & 10.6 & 20.6 \\
\hline $\begin{array}{l}\text { Mathematics and } \\
\text { natural science .. }\end{array}$ & 1,563 & 3,503 & 6.1 & 9.4 \\
\hline Law $\ldots \ldots \ldots \ldots$. & 3,179 & 7,259 & 12.3 & 19.5 \\
\hline Medicine $\ldots . . \ldots$ & 2,061 & 4,879 & 8.0 & 13.1 \\
\hline $\begin{array}{c}\text { Theology (evangel- } \\
\text { ical) } \ldots \ldots \ldots \ldots \ldots\end{array}$ & 1,036 & 1,211 & 5.9 & 5.6 \\
\hline Theology (catholic) & 330 & 1,014 & 3.5 & 8.4 \\
\hline Pharmacy ....... & 301 & 896 & 1.2 & 2.4 \\
\hline
\end{tabular}

It will be noted that the percentage increase in medicine has about kept pace with the increase in law, while the proportion of students in mathematics and natural science has not increased so rapidly as that in philological and historical studies. The number of students of evangelical theology shows a relative falling off (although a slight absolute increase), but catholic theology records a greater relative increase than any other subject.

Some interesting facts are also given respecting the extent and nature of inter-university migration. In the summer months of 1909, 28.6 per cent. of the Prussian students were registered in the German universities outside of Prussia, for the most part (18.7 per cent.) in the South German universities of Bavaria, Baden (Heidelberg and Freiburg) and Württemberg (Tübingen). On the other hand, only 5.8 per cent. of the Bavarian, 8.4 per cent. of the Baden and 10.7 per cent. of 
the Württemberg students were matriculated in Prussian universities. In Heidelberg there were 763 Prussians and 654 Badenese, and in Freiburg 1,437 Prussians and 688 Badenese, a state of affairs probably due in large part to the attractive surroundings of the two Baden universities.

\section{Edwin O. Jordan}

\section{LECTURES IN SANITARY SCIENCE AT COLUMBIA UNIVERSITY}

THE committee in charge announces the following lectures in the course in sanitary science and public health for the second term, 1909-1910:

February 1-A. H. Seymour, Esq.: "The Development of Public Health Law and the State Control of Health."

February 3-A. H. Seymour, Esq.: "Provisions of Public Health Law as applied to Specific ReguIation."

February 8-Dr. V. E. Sorapure: "Transmission and Prevention of some Infectious Diseases."

February 10-Dr. V. E. Sorapure: "Immunity."

February 15-Dr. James Ewing: "Cancer and its Relation to Public Health."

February 17-Dr. W. Gilman Thompson: "The Occupation Diseases of Modern Life."

February 22-Professor A. D. MacGillivray:

"Insects and the Transmission of Disease."

February 24-Professor A. D. MacGillivray:

"Insects and the Transmission of Disease."

March 1-Dr. John B. Huber: "Tuberculosis, its Nature and Causes."

March 3-Dr. John B. Huber: "Tuberculosis, its Prevention and Cure."

March 8-Hon. Homer. Folks: "Voluntary Organization in Public Health Work."

March 10-Dr. John H. Pryor: "Results of Tuberculosis in New York State."

March 15-Dr. E. R. Baldwin: "Early Diagnosis of Tuberculosis."

March 17-Dr. D. M. Totman: "Local Quarantine Measures."

March 22-Dr. H. H. Crum: "The Supervision of Infectious Diseases."

March 24-Dr. H. W. Wiley: "Food Adulteration and its Effects."

March 29-Professor E. M. Chamot: "The Detection of Food Adulteration."

March 31-Professor E. M. Chamot: “The Detection of Food Adulteration."
April 5-Professor W. A. Stocking: "Dangers of Impure Milk."

April 7-Professor W. A. Stocking: "Dairy Hygiene."

April 12-Dr. L. H. Gulick: "School Hygiene."

April 14-Professor G. W. Cavanaugh: "Animal Wastes and their Disposal."

April 19-Professor H. N. Ogden: "The Relation of the Engineer to Sanitation."

April 21-Mr. Geo. C. Whipple: "Principles of Water Purification."

April 26-Mr. Theodore Horton: "Water Purification Plants."

April 28-Professor H. N. Ogden: "The Problem of Sewerage."

May 3-Mr. H. B. Cleveland: "Sewage Disposal Plants."

May 5-Professor Alfred Hayes: "The Law of Nuisances."

May 12-Rudolph Hering: "The Garbage Problem."

May 17-Professor C. A. Martin: "House Planning with reference to Health."

May 19-Professor C. A. Martin: "The Healthful House."

May 26-Professor G. N. Lauman: "Health in Rural Communities. Public Health."

\section{SCIENTIFIC PUBLICATIONS FOR FREE DISTRIBUTION}

ON January 13 a resolution was passed in the House of Representatives ordering the whole stock of the scientific publications named below in the House Folding Room to be disposed of in order to make room for new documents. Any reader of Science desiring to procure any of these documents should apply to the member of congress from the congressional district in which he resides within sixty days from the date of passage of this resolution.

The publications to be distributed free are as follows:

Geological Resources, Cripple Creek, Colo.

Geological Report on Mercur Mining District, Utah.

Astronomical Papers of the American Ephemeris, Vols. 5 and 6.

Catalogue, Prehistoric Works.

Indian Languages: Algonquin, Athapascan, Chinookan, Iroquoian, Muskhoegan, Salishan.

National Academy of Sciences.-Memoirs: Vols. 